\title{
Arts, Tourism and the Environment: An Overview of Critical Intersections in Nigeria
}

\author{
Esekong H. Andrew \\ Department of Theatre and Media Studies \\ University of Calabar, Nigeria \\ esekongh@yahoo.com
}

Elizabeth Andrew-Essien

Department of Geography and Environmental Sciences University of Calabar, Nigeria liessien@yahoo.ca

Doi:10.5901/mjss.2013.v4n6p275

\section{Abstract}

This paper entitled "An overview of critical intersections of arts, tourism and the environment in Nigeria" examines the mutual dependency of arts, tourism and the environment. Art, being a major component of cultural tourism is a major driver of the tourism sub-sector in Nigeria. In its various ramifications, art mirrors its social and cultural environment and plays back to audiences, which may consist of art-core tourists and culture connoisseurs. As much as art draws its "raw materials" directly from the environment, it has the capacity in much the same to way initiate conversations at various levels towards nurturing the environment. This it does using performative, visual, literary and technology-based modes. The compatibility between arts and environment continues with arts adopting environment-friendly production materials and procedures. The paper concludes with suggestions on how the tourist could join this multi-sectorial collaboration for sustainable development.

Keywords: Arts, Tourism, Environment, Environmental Arts.

\section{Introduction}

In a world that is increasingly enmeshed in multi-sectorial collaboration and inter-disciplinarity, it has become imperative to re-examine or reposition the structures that enforce certain collaborations. Reappraisal in this regards enables optimum utilization of resources towards realizing maximum value in the sustenance of economic, political, social and other relationships realizable from such collaborations. This paper examines the mutual dependency of art, tourism and environment in a holistic perspective, and the implications for development in Nigeria. Arts and tourism exist within the network of natural, social and cultural environment, and the manifestation is mutual relatedness and support to each other. In a unique perspective, the paper examines the extent to which the arts as a cultural subset of tourism depend on the environment and at the same time impact on its multiple layers. A close attention is given to indigenous Nigerian arts, crafts and performances, and how the environment supports their production. The paper discusses how artistic souvenirs, memorabilia and festival performances, offshoots of the synergy of art and environment are patronized by tourists to continue the triangulated network of collaboration.

\section{Understanding the Arts in the Context of Development}

Basically, art is a means of self-expression but, in practical circumstances, it does more than that. Art is an experience; and Wilson (1991:6) aptly reflects that all the arts offer experiences, which make them unique. The experience of art runs through social life and is expressed mainly in visual, performative and literary terms. An examination of these forms of expression, in a broad sense, helps in understanding the arts and their role in development. Ordinarily, 'art' cannot be confined to definite limits as scholarship is now interdisciplinary. For the sake of this discussion, four broad categories, all related to tourism will be examined: 
- Visual arts, consisting of fine and applied arts and all the sub-categories - drawing, painting, sculpture, graphics, textiles, ceramics, etc.

Performing arts, consisting of theatre, music, dance, recitals, carnivals and festivals.

Literary arts, consisting of poetry, drama, prose and other forms of creative writing.

Technology-based arts, also known as the arts of the 20th century, consisting of photography, film, radio, television, video and Internet-based displays.

All these categories of art are avenues for self-expression, which engage human imagination and creativity towards satisfying aesthetic urges or fulfilling certain utilitarian or practical needs. As an extension of the later role of fulfilling practical needs, the arts have frequently been mobilized to pivot tourism, to document and communicate individual and collective experiences in time and space.

All forms of art - representational or expressionist, meant for development of any sort use basic elements and principles, the configuration of which can assume different meanings in various cultural contexts and therefore can be interpreted differently. Art products for tourism development usually display the necessary backgrounds - content, which is the message; the subject matter, which is the theme; and the iconography, which is the storyline as a clue to unlocking the culture to which they belong and for a fulfilling experience in appreciation and communication.

\section{Tourism in the Context of Arts and Culture}

According to World Tourism Organization, tourism comprises the activities of persons travelling to and staying in "places outside their usual environment for not more than one consecutive year" (http://en.wikipedia/org/tourism). Tourism is a service-based industry involving a number of tangible and intangible components. The major tangible elements include transport, foods, souvenirs, accommodation and other components of the hospitality industry, while the major nontangible elements include adventure, exposure, cultural experience, relaxation and other experiences that relate to the purpose or motivation for becoming a tourist. All these elements are projected by information and publicity, sometimes managed by specialized agencies.

Recently, tourism has developed into many subsets, including cultural tourism, ecotourism, adventure tourism, ancestry tourism, creative tourism, drug tourism, educational tourism, medical tourism, sexual tourism, mystical tourism, space tourism, cyber tourism, virtual tourism and a whole lot of other modes and incentives to travel. Most of these "tourisms", arguably, fit into the framework of 'cultural tourism' since culture is said to embrace the totality of the way of life of a people. But cultural tourism essentially focuses on culture and social environments, which may include heritage, visual and performing arts, festivals, landscape, cultural values and lifestyles on the one hand, and cultural facilities such as museums, galleries, theatres and historic sites on the other hand. In every case, the motivation for travelling is usually culture-based. Hughes describes people who travel in order to visit cultural attractions as 'culture-core tourists' and those who travel for some non-culture purpose but who also visit cultural attractions as 'culture-peripheral tourists'. In much the same way, he describes those who travel primarily to see arts as 'art-core' tourists, and those who travel for some nonart purposes but who also visit art attractions as 'art-peripheral' tourists (Hughes 2000:3). Some arts, entertainment and cultural functions such as the Hollywood Film Festival, Oscar Awards in the United States, Sotheby Arts Auction in United Kingdom, the emerging Nigerian carnivals in Calabar, Abuja, Lagos and Port Harcourt, and many others have the ability to pull art connoisseurs from distant locations. Some cultural functions also lure visitors who may have travelled for other purposes. It can therefore be said that in today's world, the distinction between arts and tourism is blurred. At a glance, art seems to impact on tourism in the following directions:

- $\quad$ Art encourages people to visit specific locales.

- $\quad$ Art helps people from different cultures to have a deeper understanding of each other.

- $\quad$ Art reflects society and culture, and communicates to audiences.

- $\quad$ Art can provide economic sustenance.

From a deeper perspective, art in tangible or performative forms can preserve memories and experiences of parent cultures for tourists who collect or experience them. Tangible art forms such as paintings, sculptures, ceramics and textiles with indigenous themes and styles are sold commonly at airports, hotels and tourist sites as souvenirs and mementos to interested tourists. Art and cultural institutions like galleries, museums and history bureaus provide contact points for tourists. Similarly, art-related activities such as fairs, expos, carnivals, exhibitions, auctions and festivals provide points of interaction between tourists, arts and artists. Cultural festivals, owing to their theatrical nature, tend to lure more tourists than formal exhibitions of tangible arts and crafts. In festivals, there are usually avenues for sub-artistic expressions for the actor/performer, the director, the designer and other collaborators of the ensemble. Generally, 
cultural institutions and artistic festivals showcase ideas and products that represent the host cultures. Art is therefore a promotional tool for tourism. How, then, can the intersections between arts and tourism be critically assessed within a super-active environment like Nigeria? Perhaps an examination of the Nigerian 'artscape' will help illuminate the arts and tourism complex.

Nigeria has a rich cultural artistic heritage that dates back to more than two thousand years (Eyo 1977: 7). The claim applies to both tangible and performative arts. With reference to tangible arts, indigenous artistic ideas have been replicated over the years for the interest of collectors (Willet 1981:194,197). Many craft pieces have been reproduced with locally obtained materials for commercial purposes. Clusters of craftsmen are found in cities across Nigeria that specialize in some forms of craft. Benin and Ikot Ekpene are Nigerian cities noted for the varieties of crafts they produce. Many craft centers specialize in specific crafts that generally depend on the type(s) of raw materials available in their environments.

The tendency in craft production is for artists to explore their immediate environment and to use materials that are readily available. Any material can become valuable for craft production, depending on the dexterity and resourcefulness of the craftsman. Following the assumption that availability of materials within an environment encourages the production of arts and craft, one can easily relate certain crafts to specific locales in Nigeria. Wood carving, for instance, is predominant in the forest belt where the raw materials are available; cane work is common in the riverine areas; raffia and mat weaving are practiced in the palm belt. Calabash decoration, pottery, stone carving, dyeing and many other crafts are practiced in environments where the raw materials are available (See table 1). This does not mean that raw materials cannot be transported to locations where they are not commonly available. For example, some residents of Calabar, Nigeria are known to engage in brass beating and beading yet brass and beads are not produced in the area, but are imported via trade routes. Whether raw materials are obtained locally or imported to certain locales, most materials used for the production of graphic and plastic arts and crafts are obtained from the physical environment. This implies that there is a relationship between raw materials for artistic creation and the physical environment.

Table I: Indigenous Nigerian Crafts and Places of Production

\begin{tabular}{|l|l|}
\hline Craft & Place(s) of Production \\
\hline Raffia work & Ikot Ekpene \\
\hline Wood Carving & $\begin{array}{l}\text { Benin, Ikot Ekpene and some other towns in the } \\
\text { forest belt }\end{array}$ \\
\hline Calabash Decoration & $\begin{array}{l}\text { Kano, Kaduna and some other Northern Nigerian } \\
\text { towns }\end{array}$ \\
\hline Leather Work & Sokoto, Kano, Maiduguri, Bornu, etc. \\
\hline Stone Carving & Northern Cross River, Esie \\
\hline Dyeing & Abeokuta, Kano \\
\hline Pottery & $\begin{array}{l}\text { Abuja, Jos, Akwa Ibom, Ogoja and other places with } \\
\text { significant clay deposits }\end{array}$ \\
\hline Bead Work & Benin, Calabar, Bida \\
\hline Brass Beating & Calabar \\
\hline Brass/Bronze Casting & Benin, Ife \\
\hline Chewing-stick Carving & Calabar \\
\hline Weaving of sleeping, roofing, wall and decorative mats & Niger Delta and other coastal settlements \\
\hline Coconut Shell Carving/Decoration & Akwa Ibom, Cross River \\
\hline *Source: Field Work. List can be extended to cover other known crafts and locales of production \\
\hline
\end{tabular}

Nigerian arts can be found in most major art collections in galleries and museums across the world. For instance, the original ivory mask from ancient Benin that was used as a symbol for the Festival of Arts and Culture (FESTAC) in Lagos, 1977 is kept in the British Museum. 


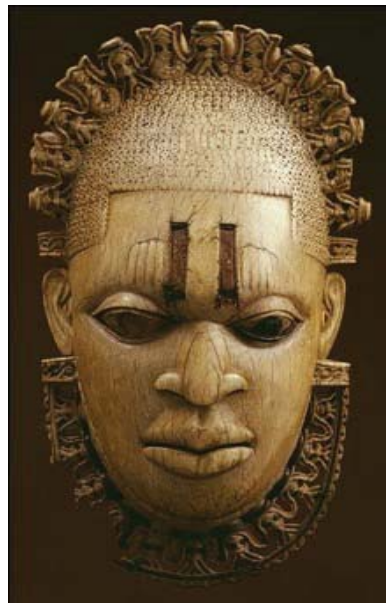

Plate I: Ivory mask from ancient Benin used as symbol for FESTAC '77

Interestingly, a number of Nigerian arts in foreign collection were 'stolen', hence the persistent calls by successive Nigerian governments, art organizations and individual stakeholders for reparations from countries that are still keeping them illegally. Perhaps, the earliest recorded case of looting of Nigerian arts and craft was when British troops invaded the ancient Benin Empire to retaliate the killing of British nationals by local authorities in 1897. During this invasion, popularly referred to as the 'Punitive Expedition', numerous Nigerian art pieces were illegally taken to Europe (Eyo 1977:132). Smuggling of Nigerian art continues to the present day, at times aided by Nigerians in what has become a multimillion Dollar illegal trade. Perhaps the only bright side of this illegality is the fact that indigenous Nigerian arts and craft products are increasingly popular, as they remain irresistible to collectors and tourists across the globe.

Apart from tangible arts, performing arts and festivals also form parts of Nigeria's cultural and artistic heritage. The Argungu Fishing Festival in Kebbi, Durbar Festivals in Kano and Katsina, the Igue Festival in Benin City, the Mmanwu Festival in Enugu, the Oshun Festival in Oshogbo and the New Yam Festivals of South Eastern Nigeria are long standing festivals that have lured millions of tourists to Nigeria over the years. Jemi-Alade observes a conceptual expansion of the Argungu Fishing Festival from an ordinary fishing competition featuring few fishermen with hand nets and gourds in the late 30 s to a cocktail of artistic activities, including traditional water sports such as swimming, diving, wild duck catching; wrestling, arts and craft exhibition, agricultural shows; horse and camel racing, traditional music entertainment and excursions to ancient palaces and sites.

(www.africa-ata.org.org/nigeria).

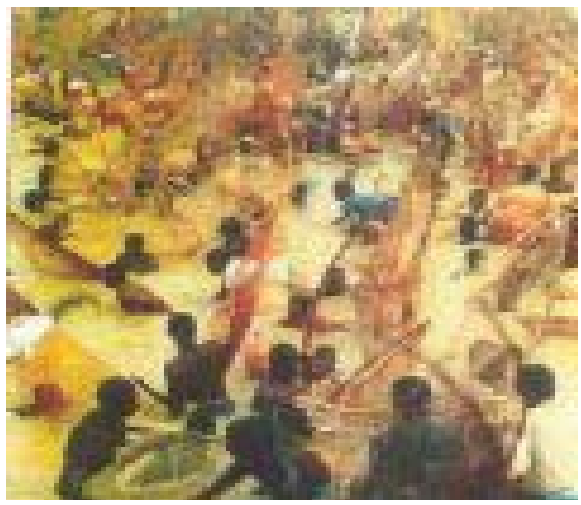

Plate II: The Argungu Fishing Festival in Kebbi, Nigeria. 
Similarly, the Igue Festival in Benin City initiated in 1440AD has expanded in scope, featuring arts exhibition, dance performances with the Oba in the ensemble, and tours of ancient Benin, Abraka and the Nana museum (http://www.africa-ata.org/nigeria). The Abuja, Lagos and Calabar Carnivals are newer additions to Nigeria's list of performative/festive productions where a variety of Nigerian dances, costumes, music and other art forms are displayed for an international audience.

Apart from utilizing certain production elements from the physical environment, performing arts and festivals draw concepts largely from social and cultural environments. Themes of festivals are always related to socio-cultural ambiences. This development is significant being that tourism is a social venture and that tourists would always want to gain an insight into new cultures using arts among other cultural indices.

The claim that Nigeria contributes significantly to global cultural artistic heritage can be buttressed further by the fact that at least two Nigerian artistic/cultural centres - The Sacred Groove at Oshogbo, Oshun and Sakur Cultural landscape at Adamawa, are cited in the Unesco's Cultural Heritage list. Six other cultural sites have been kept on Unesco's tentative list of World Heritage Centres. Among the six are Benin/lya Sungbo Eredo cultural site, Kwiambana/Ningi, Oban Hills and Niger Delta Mangroves, which are already active tourist locations in Nigeria. Others are the Gasshaka-Gumpti and Old Oyo National Parks, which are popular sites for ecotourism expedition in Nigeria (http://whc.unesco.org).

\section{Arts and Craft in the Environment}

Although tangible and performative arts are products of the physical, social and cultural environment, complex relationships would demand a closer examination. It would be necessary to study the nature of the environments that habour these complex cultural forms. For man, or any organism for that matter, environment is the surrounding space. But the environment can be more complex when taken as a social question. Cunningham and Saigo observe: "humans have always inhabited two worlds. One is the natural world...the other is a world of social institutions and artefacts that we create for ourselves..." (2001:17). In this sense, the environment is all of the following:

- The circumstances or conditions that surround an organism.

- The complex of social or cultural conditions that affect an individual or community. (Cunningham and Saigo 2001: 17)

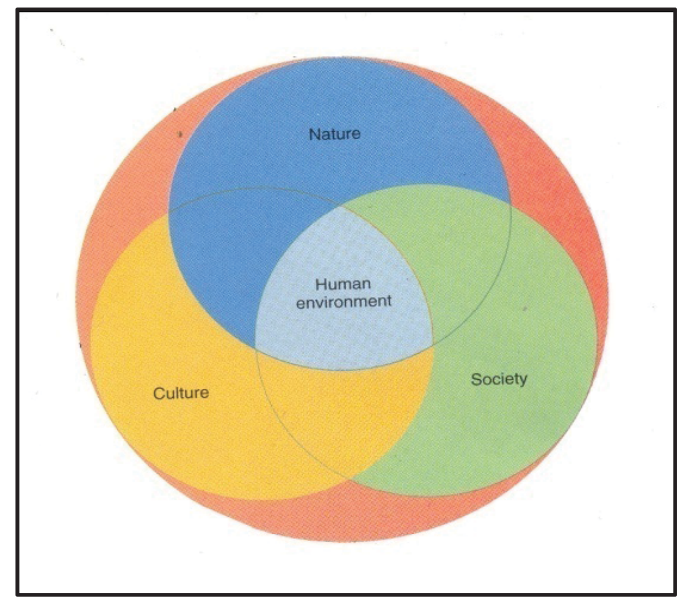

Fig 1: Intersections of the natural world and cultural worlds encompass our environment. (Diagram courtesy: William Cunningham and Barbara Saigo, 2001)

The environment as encapsulated in the definition above is essential to arts and tourism. For instance, art derives raw materials and in some cases concepts from the natural environment. But of greater interest is the socio-cultural environment, which has often been described as 'built' environment because it is created and conditioned by man (Cunningham and Saigo 2001:17, Chokor 1993:1). This environment consists of both cultural and social components, 
both of which impact strongly on each other. Matsumoto argues that indeed culture creates the structure by which rules of social interactions are maintained (1997:47). Art is a component of the socio-cultural environment and members of this social space find a means of expression through art forms. The dynamic relationship between arts and the environment can be appraised from two perspectives. First, in terms of the benefits the arts derive from the environment, and then in terms of the benefits the environment derives from the arts.

From the first perspective, what readily comes to mind is the fact that the 'environment' provides 'raw materials' for art production. For centuries artists have drawn materials from the natural environment. The raw materials may be tangible such as those used for the creation of 'solid' arts and crafts. Quite often, materials obtained from natural environments are refined before they are put to use. The processes of refining may be crude or basic, such as the act of sieving clay manually before using it for pottery; or sophisticated, such as the scientific processes of producing colourants from organic materials or simulating from inorganic sources.

Apart from tangible raw materials, the environment also provides social raw materials, which are of great importance because they induce creative inspiration and determine the contexts and subjects of artistic creation. Willet identifies this social element in art works from many African cultures. Using mask forms from various African cultures as case studies, he submits that social circumstances determine production and usage $(1981: 172,173)$.

The influence of the socio-cultural environment on art probably dates back to the Palaeolithic Age. The cave drawings of this age depicted hunting and gathering, which were predominant social activities of the period. In what seems to be a transmitted tendency, the environment also constitutes the dominant theme in English arts. Peat observes an affiliation between English arts and the environment stating that in Britain, "art reflects landscape (and community) and landscape art" (www.fdavidpeat.com). He traces this affiliation to early creative art products and literary works, citing the "flight... into benevolent nature in the forest of Arden" in Shakespeare's As you Like It; the Ballads of Robinhood; the fictions of John Wyndham and John Christopher; and the outdoor sculptures of Henry Moore as literary and visual examples of works inspired by the environment. As an extension of the affinity between arts and the natural environment, man frequently attempts to 'reshape' natural forms to suit his aesthetic standards, which are socially determined. This instinct may have given rise to such arts/practices as landscaping, lawn mowing, hedge/trees pruning and gardening among other activities that seem to harmonize man, his aesthetic inclinations and the environment.

Another dimension of the relationship between art and environment is found in the concept of 'environmental arts', which has been defined as art that helps improve relationship with the natural world (www.greenmuseum.org). This concept can be explored in three trajectories:

1. Using art to communicate the values of environmental conservation. One of the most famous examples of environmental art in Nigeria could be found in Tes Onwueme's dramatic text, The Desert Encroaches, which is plotted around environmental issues. Another dramatic art project which was conceived to address the environment was a Theatre for Development (TfD) project sponsored by Living Earth Foundation at the community level to raise environmental awareness in selected communities in Northern Cross River State, Nigeria. Liwhu Betiang, Freedom Ejom and Barclays Ayakoroma, all theatre practitioners in Nigeria were consultants in this project, which TfD was used as the main methodology to sensitize the target communities on environmental conservation and forest management. As part of the project, a number of dramatic scripts on environmental resource management were written among which were Our Forest, Our Future, a compendium of plays on the environment written by Liwhu Betiang, Freedom Ejom and Barclays Ayakoroma, and Ekanakwor (The Forest) written by Arikpo Arikpo and Freedom Ejom. Both works were published by Living Earth Nigeria Foundation in 2000.

2. Using natural and environment-friendly materials to create art. Most Nigerian crafts fit into this category, so do some experimental mixed-media appliqué creations of painting, sculpture and pottery. Nigerian stone carvings, local pottery, weaving and other industries built around Indigenous Knowledge Systems (IKS) arguably, use mostly environment friendly materials.

3. Displaying and appreciating art as part of environment. Many outdoor sculptures and water fountains displayed at appropriate locations fit into this category. Such displays are found at road junctions, parks, gardens and squares in many modern Nigerian cities. Outside Nigeria, a popular example of art becoming a part of the environment is in the work of Frank Lloyd Wright, the acclaimed American architect who was noted for his advocacy for harmony between artistic structures and natural elements - slopes, rocks, hills and waterfall. Wright's architectural masterpiece, Fallingwater (1935) in Bear Run, Ohiopyle, Pennsylvania, built on a waterfall, is a vivid example of artistic and natural synthesis. This work has been appropriately described 
as "Organic Architecture - the union of the structure and the land upon which it is built". (http://www.netserves.com/flw/flwbook1.htm)

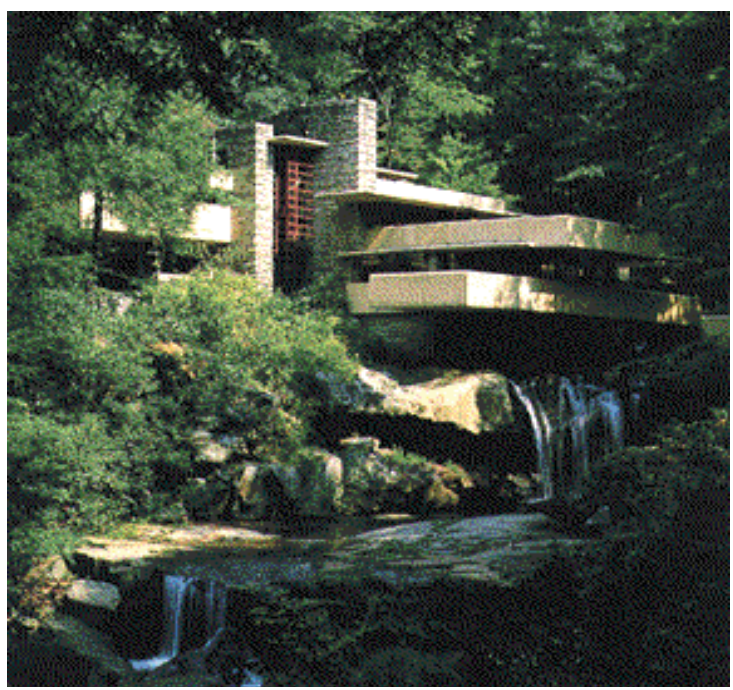

Plate III: Frank Lloyd Wright's Fallingwater (1935)

Satish Kumar, the environmentalist, quoted in Peats (2007) argues in support of making art a part of the environment. He argues against what he calls "the fragmentation of art from environment" maintaining that by abstracting art and placing 'the beautiful' in galleries, we end up making our lives and environment intolerably ugly. Kumar insists that art leaves the gallery or any artificially organized setting to join the environment and enter into the landscape.

Apart from providing the experiential and material resources with which the artist generates a concept, environment gives space for appreciation. Space itself is an integral part of design. Without space, there is no design. The environment provides all the artistic spaces where works of art can exist and be appreciated in-the-round. The space provided by the environment for arts in-the-round, including performances is contiguous with the space occupied by the tourist. This is to say that environment also provides space in which the tourist interacts with arts. In a wide context, space may appear elastic or limitless, but it can be bridged by movement in time.

The second perspective from which the relationship between arts and environment can be examined is in terms of contributions of art to environment. This can be analyzed in terms of positive and negative effects. On the positive side, visual art beautifies the physical environment. As stated earlier, outdoor sculptures, paintings, graphics, lighting, architectural and other visual art forms have been used to decorate cities at parks, public buildings, road interjections and private quarters. To a large extent, these visual art forms become a part of the environment, define the character and become a part of the description of the places in which they exist. One's mental image of major cities of the world includes their artistic or aesthetic character. For instance, it is difficult to think about New York without reflecting on the Statue of Liberty or to visualize Paris without the Eiffel Tower. Similar landmark artistic or architectural pieces are found in many major cities of the world. The artistic character or order in a city could make the difference between one city and the other or one tourist centre and another.

Art also benefits the environment by documenting natural and cultural features and landmarks visually for references. Such features could be documented as paintings, sculptures or in video. In an age of industrialization and urbanization, the natural landscapes of many places are continually threatened by physical development projects. Art can document sceneries and preserves memories of places. For example, memories of the mangrove forests of the Niger Delta, which have been changing because of human exploration, would have been lost save for photographs and artistic images that were taken at earlier periods. For example, John Hughes's painting of the Calabar Seaport in 1880 is one of the earliest existing visual images of the old Calabar seaport. This image contrasts with the current scenario of the seaport as shown in Plates IV and V. 

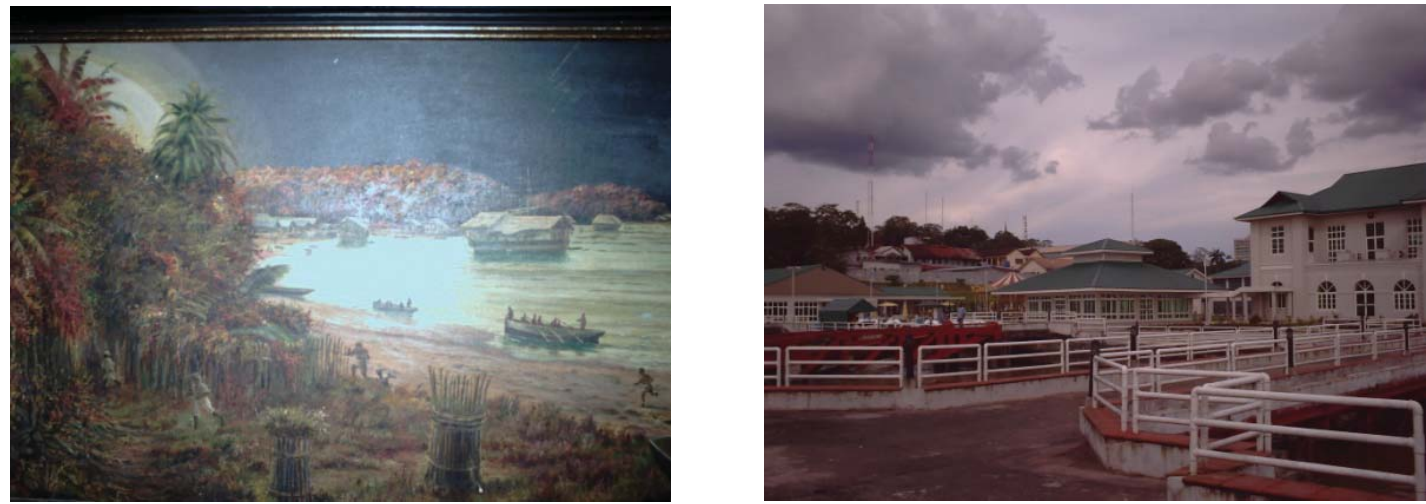

Plate IV and V: John Hughes's painting of Calabar Seaport in1880 (Left) and a photograph of the same location of the port, now developed into a tourist resort, 2007 (Right). Photographs taken with permission from the National Commission for Museums and Monuments, Old Residency Museum, Calabar, Nigeria.

Paintings, sculpted images and photographs/postcards of natural environments and socio-cultural gatherings and festivals are some of the fastest-selling images in the Nigerian art market.

Art communicates socio-cultural values to audiences. As art derives concepts from society, it mirrors society and projects its norms and values. By mirroring the social environment, art creates the possibility of correcting identified societal ills. Tourists benefit greatly from this function of arts and often find it easy to relate with cultures whose glimpses they have had, maybe through video films, cinemas and the Internet. Electronic communication systems have facilitated the production and transmission of socio-cultural values.

On the negative side, arts can deplete and pollute the physical and social environment. If art derives its raw materials from these environments then it is possible that it also scars it in some way. For instance, to obtain wood for carving and furniture, the forest is exploited for timber. Similarly, dozens of stands of raffia palm must be felled to obtain raffia and other fibres for craftwork. In exploiting the eco-system, the ecological structure is destabilized. Environmental conservation experts can best analyze the effects.

Furthermore, processing of art materials may involve sawing, filling, sanding and other physical and chemical processes that could emit pollutants that are harmful when inhaled, absorbed or ingested by man and other organisms. Many health and safety organizations are springing up to address safety and health issues for the arts worldwide, one of which is the Arts, Crafts and Theatre Safety (ACTS) organization founded by Monona Rossol in the United States. ACTS provides health, safety, industrial hygiene, technical services, and safety publications to the arts, crafts, museums, and theatre communities across the globe (http://artscrafttheatresafety.org).

Ability to keep a clean environment has become a strong selling point for tourism. For example, the Cross River State of Nigeria, while making a serious attempt to sanitize its physical environment, has adopted the slogan: 'Clean and Green' in its campaign to lure tourists to its domain. Art, in the process of complementing tourism, should not undermine the accelerating campaign for a clean environment, which can, in turn, promote tourism.

From the socio-cultural perspective, art, while replicating society can also project negative images. In this regard, Belton's (1994:143) critique of the film, Pretty Woman (1990) as a work of art is a disturbing disclosure of a society's attempt to 'reform prostitution', projecting immorality as it were. In much the same way, many Nigerian films, based on indigenous Nigerian cultures and festivals are observed to be propagating ancestral rituals (Ugor 2004:72), witchcraft (Okome 2000:47) and barbaric fetish practices (Offiong 2005:113). But the Nigerian society is not all about 'negative' notions. Many 'positive' qualities also arise from the same society. But it would appear that audiences are naturally inclined to artistic productions with uncommon cultural rituals and supernatural elements. Emem Isong, a foremost Nigerian movie producer, confirms this speculation in an interview with Onookome Okome, a film scholar and critic (Okome 2000:48). Negative images projected through the media can impact on the social environment. They may develop wrong impressions, which can suppress the development of tourism. 


\section{The Role of the Tourist}

What then is the place of the tourist in all these complexities? The tourism experience cannot be complete without the tourist. Quite often, tourism has been appraised from a negative perspective and issues relating to acculturation, propagation of social vices, health epidemics and environmental degradation have been raised; and the tourist has been fingered as being at the forefront of introducing these negative issues. Since tourism as a major human activity cannot be abolished, it would be better to deliberate on related positive developmental issues. For instance, the possibility of the tourist contributing to the development of arts and tourism within the identified environments should be examined.

The tourist who appreciates the arts of a given locale or environment is in a frontline position to promote tourism. The tourist can do a critical appraisal of the tourism package available within an environment. Particular issues can be addressed, ranging from accommodation and catering facilities, to marketing outlets and security issues and a lot more. The essence would be to contribute to better packaging of ideas for the development of tourism within a given area.

The tourist aids in revenue generation thereby energizing the local economy. This is done by patronizing commercial facilities and items - arts and craft mementoes and souvenirs, performances and festivals, hotels, catering and recreation facilities that may be available within a tourist destination. Sustained patronage can create employment opportunities in viable sectors.

The tourist may invest in the development of infrastructures such as galleries, museums, theatres, hotels, recreation parks and communication facilities. Tourists can also start foundations to support tourism initiative within a locale. The "Happy World, Happy Land" multi-purpose entertainment project at the Lekki beach, Lagos, modeled after Disneyland in Europe, is one of such joint foreign and private sector initiatives (Ekpenyong 2000:549). Tourists may open avenues for collaboration between institutions for exchange of programmes, personnel and technical facilities for the development of tourism

\section{Conclusion}

This chapter has examined the tangible and performative components of arts and their abilities to give insight to cultures to which they belong. It has been observed that arts in all ramifications obtain 'raw materials' and inspiration from the physical, cultural and social environments. In giving back to society, art beautifies and communicates. Tourism, with all it represents, keys into the aesthetic and communicative potential of art to enhance social interaction between people and cultures. These interactive processes have been illustrated using Nigeria - a vibrant cultural entity where the graphic and plastic arts; performing arts and cultural festivals project indigenous cultures to local and international audiences.

The relationship between arts, tourism and environment may be complex. One thing is however remarkable: each component impacts upon the other for the collective benefit of society. In discussing arts, tourism and environment, emphasis should shift from the negative effects of this interaction, namely, pollution, health and acculturation issues, to positive effects which should include the possibility of cross cultural dialogue and conflict resolution arising from enhanced knowledge of global cultures. Possibilities of propagating positive cultural practices embedded in arts and festivals should be discussed. In doing this, the technologies of the 20th and 21st centuries - television, video, film, Internet, etc, should be utilized to reach out to wider audiences. An implication to this would be that artists will be challenged to enhance not only cultural but also technical literacy for self-expression and creative solutions towards addressing the needs of tourists and tourism as an industry.

Arts, tourism and the environment exist in one nexus that can hardly be dismantled. It has become imperative to mediate the effects of this interaction and to infuse cultural and scientific changes and innovations without upsetting the existing balance. At every turn, one must remember the major commitments of mankind in the 21st century - to preserve the environment for posterity and to communicate positive cultural values for future references.

\section{References}

Arikpo, Arikpo and Freedom Ejom. (2000) Ekanakwor (The Forest). Port Harcourt: Living Earth Foundation.

Belton, John. (1994) American Cinema: American Culture. New York: McGraw-Hill.

Betiang, Liwhu, Freedom Ejom and Barclay Ayakoroma. (2000) Our Forest, Our Future. Port Harcourt: Living Earth Nigeria Foundation.

Chokor, B.A.(1993) "Perspectives on Environment and Tourism in Nigeria". Environment and Tourism in Nigeria. B.A. Choko ed. Lagos:

EBAN, pp.1-12.

Cunningham, William and Barbara Saigo. (2001). Environmental Science: A Global Concern. New York: McGraw-Hill. 
Ekpenyong A.J.U. (2000) "Recent Developments and Future Prospects in the Tourism Industry". Nigeria: A People United, A Future Assured. H.I. Ajaegbu, B.J. St Mathew-Daniel and O.E. Uya (eds.) Abuja: Federal Ministry of Information. pp. $547-552$.

Eyo, Ekpo. (1977) Two Thousand Years Nigerian Art. Lagos: Federal Department of Antiquities.

Garry Marshall. (1990) Pretty Woman.

Gilbert, Rita and William McCarter (1988). Living With Art. New York: Alfred A. Knopf.

Hughes, Howard. (2000) Arts, Entertainment and Tourism. Oxford: Butterworth Heinemann.

Jemi-Alade, Ladi. "Nigerian Festivals and Cultural Tours". Africa Travels Magazine. (http://www.africa-ata.org/nigeria).

Wilson, Edwin. (1991) The Theatre Experience. New York: McGraw Hill.

Matsumoto, David. (1997) Culture and Modern Life. New York: Brooks/Cole.

Offiong, E.A. (2005) "Video Films as Mediators of Pentecostal Christianity in Nigeria: A Case Study of Liberty Video Films" WAACLALS Journal. Vol. 2, No.1, pp.106 - 119.

Okome, Onookome. (2000) "Naming Suffering and Women in Nigerian Video Film: Notes on the Interviews with Emem Isong". Ndunode: Calabar Journal of Humanities. Volume 3, No. 1, pp. $43-56$.

Onwueme, Tess. (1985) The Desert Encroaches. Owerri: Heins, Nigeria Publishers.

Peat, David F. (2007) "Art and the Environment in Britain" (http://www.fdavidpeat.com). Retrieved March 2007.

Ugor, Paul. (2004) "Folklore, History, Identity and Social Critique: Classifying Popular Indigenous Igbo Films". Theatre Studies Review. Vol. 4 No.1, pp. 64 - 78.

Willet, Frank. (1981) African Art. London: Tames and Hudson. 